This item was submitted to Loughborough's Research Repository by the author.

Items in Figshare are protected by copyright, with all rights reserved, unless otherwise indicated.

\title{
Strategic B2B customer experience management: the importance of outcomes-based measures
}

PLEASE CITE THE PUBLISHED VERSION

https://doi.org/10.1108/JSM-10-2016-0350

\section{PUBLISHER}

(C) Emerald

VERSION

AM (Accepted Manuscript)

\section{PUBLISHER STATEMENT}

This work is made available according to the conditions of the Creative Commons Attribution-NonCommercialNoDerivatives 4.0 International (CC BY-NC-ND 4.0) licence. Full details of this licence are available at: https://creativecommons.org/licenses/by-nc-nd/4.0/

\section{LICENCE}

CC BY-NC-ND 4.0

\section{REPOSITORY RECORD}

Zolkiewski, Judy, Vicky Story, Jamie Burton, Paul Chan, Andre Gomes, Philippa Hunter-Jones, Lisa O'Malley, Linda D. Peters, Chris Raddats, and William Robinson. 2019. "Strategic B2B Customer Experience Management: The Importance of Outcomes-based Measures”. figshare. https://hdl.handle.net/2134/26175. 
This is a preprint (non publisher's document). Please cite the published article: Zolkiewski, J., Burton, J., Chan, P., Robinson, W., Story, V., Gomes De Souza, A., Hunter-Jones, P., O’Malley, L., Peters, L. D. \& Raddats, C. 30 Apr 2017 In : Journal of Services Marketing. 11, 1, p. 109-126, DOI:

\title{
Strategic B2B Customer Experience Management: The Importance of Outcomes-Based Measures
}

\begin{abstract}
Purpose

The purpose of this paper is to critique the adequacy of efforts to capture the complexities of customer experience (CE) in a business-to-business (B2B) context using input-output measures. The paper introduces a strategic customer experience management framework to capture the complexity of B2B service interactions and discusses the value of outcomesbased measurement.
\end{abstract}

\section{Design/Methodology/Approach}

This is a theoretical paper that reviews extant literature related to B2B customer experience and asks fresh questions regarding $\mathrm{B} 2 \mathrm{~B}$ customer experience at a more strategic network level.

\section{Findings}

The paper offers a reconceptualisation of B2B customer experience, proposes a strategic customer experience management framework, and outlines a future research agenda.

\section{Research Limitations/Implications}

This paper is conceptual and seeks to raise questions surrounding the under-examined area of B2B customer experience. It offers a framework that is propositional in nature and will thus benefit from further empirical interrogation.

\section{Practical Implications}

Existing measures of customer experience are problematic when applied in a B2B (services) context. Rather than adopting input- and output-based measures, widely used in a businessto-consumer (B2C) context, a B2B context requires a more strategic approach to capturing and managing customer experience. Focusing on strategically important issues should generate opportunities for value co-creation and are more likely to involve outcomes-based measures.

\section{Social Implications}


Improving understanding of customer experience in a B2B context should allow organisations to design better services and consequently enhance the experiences of their employees, their customers and other connected actors.

\section{Originality/Value}

This paper critiques the current approach to measuring customer experience in a B2B context, drawing on contemporary ideas of value-in-use, outcomes-based measures, and 'big data' to offer potential solutions to the measurement problems identified.

\section{Key words: B2B customer experience, B2B services, outcomes-based measures}

\section{Introduction}

Customer experience is an important driver of business success and competitive advantage (Lemon and Verhoef, 2016) and has attracted a great deal of attention across private and public sectors, business-to consumer (B2C) and business-to-business (B2B) markets. Recognising that "what people really desire are not products but satisfying experiences" (Abbott, 1955, p.40), practitioners have sought to better understand customer engagement for some time (McColl-Kennedy et al., 2015). More recently, academic attention has also turned in this direction, belatedly recognising the links between customer experience, customer satisfaction and long-term relationships (Palmer, 2010), although this interest has tended to come from B2C rather than B2B researchers.

Customer experience is complex, dynamic and difficult to capture. It is multi-dimensional in nature (Schmitt, 2003; Verhoef et al., 2009, Lemon and Verhoef, 2016) encompassing customer responses to all the interactions they have with a firm (Homburg et al., 2015). Interactions with other actors and resources external to the firm, including, other customers (Lemon and Verhoef, 2016), intermediaries (Payne and Frow, 2004) and wider network actors (Story et al., 2016) may also impact customer experience. Customer experience is "holistic in nature involving the customer's cognitive, affective, emotional, social and physical responses to any direct or indirect contact with the service provider, brand or product across multiple touchpoints during the entire customer journey” (McColl-Kennedy et al., 2015, p.431). The strategic purpose of measuring customer experience is to use this knowledge to support positive and desirable customer experiences, so that higher levels of long-term loyalty are achieved. Aspects of service delivery that facilitate positive experiences can be designed in-line with overall strategy and firms can develop customer experiencefocussed capabilities (Homburg et al., 2015). 
Customer experience is both important and elusive and efforts to measure and manage it attract a great deal of research attention within services marketing. However, because it is difficult to capture, commitment (Geyskens et al., 1999; Gounaris 2005), customer satisfaction and/or service quality are widely used as proxy measures of customer experience (e.g. Homburg, et al., 2014). Additionally, while the majority of existing work in the services context focuses on consumer experiences, very few research papers explicitly consider business customer experiences (e.g. Payne and Frow, 2004; Biedenbach and Marell, 2010, Lemke et al, 2011). This limited academic focus on understanding how to measure customer experience in B2B (service) contexts (Jayawardhena et al., 2007; Palmer 2010) is surprising given the importance of interpersonal interactions in B2B services, and that most customer encounters are not one-off experiences but part of a broader endeavour to build and maintain long-term relationships (Meyer and Schwager, 2007; Palmer, 2010). Furthermore, as these relationships drive sustainable competitive advantage, through trusted network partnerships (Chumpitaz Caceres and Paparoidamis, 2007), understanding customer experience in a B2B context is crucial.

Often there is a focus on customer perceptions of interactions in a single customer journey, e.g., McColl-Kennedy et al., (2015). This may be helpful where an individual consumer is the user, because their experience is individually perceived, but neglects the additional complexities embodied when the networked nature of individual consumption is recognised (Epp and Price 2011; Edvardsson, Tronvoll and Gruber 2011). Such an approach is also unlikely to be helpful in a B2B (service) context, where there are usually multiple actors, including, service providers (actors selling and delivering the offer), client customers (including buyers, managers and board members) and client users of the service (Wynstra, et al., 2006). Thus, the notion of a singular journey is overly simplistic. For example, if we consider building services providers, the salespeople may attempt to sell managed office space to a client and, thus, be concerned with positively influencing the customer experience in order to develop a relationship with the client's manager or buyer. However, the users of the service are likely to be different actors (both from within and outside of the client's organisation), whose experiences are shaped by frontline staff working and other service users (such as other workers and visitors).

In a B2B context there are multiple actors, interacting in different ways (Håkansson et al., 2009), with different sets of objectives depending on their role (e.g. buyer versus user) and different individual perceptions (Mikolon et al., 2015). This not only demands that we 
consider the variety of customer journeys but also that we identify more appropriate measures of customer experience that can evaluate this diversity. Table 1 below illustrates a potential example of this complexity identifying different client and provider actors that could be involved in such a process.

\begin{tabular}{|c|c|c|c|}
\hline $\begin{array}{l}\text { Client actors } \\
\text { involved }\end{array}$ & $\begin{array}{l}\text { Experience related } \\
\text { to }\end{array}$ & $\begin{array}{l}\text { Provider actors } \\
\text { involved }\end{array}$ & Visualisation \\
\hline $\begin{array}{l}\text { Senior managers and } \\
\text { contracts department }\end{array}$ & $\begin{array}{l}\text { Purchase process and } \\
\text { other interactions } \\
\text { relating to the } \\
\text { contract }\end{array}$ & $\begin{array}{l}\text { Sales team, senior } \\
\text { managers, contracts } \\
\text { team }\end{array}$ & \\
\hline \multirow[t]{3}{*}{ Service providers } & $\begin{array}{l}\text { Interactions with } \\
\text { provider staff during } \\
\text { internal service } \\
\text { provision/delivery }\end{array}$ & Service providers & \\
\hline & $\begin{array}{lr}\text { Interactions } & \text { with } \\
\text { other client } & \text { staff } \\
\text { during } & \text { service } \\
\text { provision } & \end{array}$ & & \\
\hline & $\begin{array}{l}\text { Interaction with } \\
\text { contracts } \\
\text { department/senior } \\
\text { managers/managers } \\
\text { with respect to } \\
\text { service provision }\end{array}$ & & \\
\hline End service users & $\begin{array}{l}\text { Interaction with } \\
\text { service providers }\end{array}$ & Service providers & \\
\hline
\end{tabular}

\section{Table 1 Actor Complexity}

The 'end user' could be an actor in the client firm but could also be an actor from the client's network (e.g. the client's customer or supplier). Currently, end user experience is often considered by an evaluation of interactive episodes with frontline service staff (in the same way as consumer experiences might be evaluated). However, there are other user journeys that need to be incorporated. For example, senior management and/or buyers may be involved in procurement, and their experience is often measured cognitively using perceptions of relationship strength (Barry and Terry, 2008). Thus, to fully explore customer experience in a B2B context, these different and potentially conflicting customer journeys need to be fully appreciated. 
Concerns about customer experience measurement are expressed by practitioners across many sectors, including the amount and quality of (end user) feedback and the ability to analyse and respond to insights generated in a timely manner (Ordenes et al. 2014; Palmer, 2010). Given the numerous unresolved conceptual and methodological issues associated with the measurement of customer experience (Manary et al., 2013), this paper explores how it can be understood and operationalised in a B2B context, offering a critique of current measures and potential solutions to these problems through using alternative outcomes-based measures and the opportunities embedded in 'big data'. Vignettes from different B2B contexts are used to illustrate this.

We then develop a conceptual framework that acknowledges the complexity of measuring customer experience and provides a basis for further research. Essentially, we argue that there is a strategic opportunity to capture outcomes-based (not input- or output-based) measures. Outcomes will certainly be more difficult to 'capture'. However, outcomes-based measures can better support strategic conversations between the parties involved, enabling them to focus on critical activities within each customer journey, in order to co-create better user experiences. In support of this focus on outcomes-based measures, we contend that other data, beyond user's perceptual data, should be employed to enhance customer experience measurement and management. For example, 'Big Data', positioned at the convergence of the Internet of Things (IoT), the Cloud and smart assets (Bughin et al., 2010), could generate better insights into clients' user experiences without needing to ask them directly. In light of this we present a research agenda for further development of the area.

The paper starts by reviewing customer experience definition and measurement literature; it then explores outcomes-based measures and big data literature to offer insights into how these might enhance measurement of customer experience in a B2B (service) context. We then present our reconceptualisation; focused on a more strategic, dynamic and co-creation oriented approach to understanding B2B customer experience. Finally, we discuss how an outcomes-based, multi-actor approach to measuring customer experience in a B2B (service) context might be further studied and developed, discussing the limitations of our theorising and highlighting areas for future research.

\section{Theoretical Background}




\section{Customer Experience}

Customer experience has attracted much research attention across a variety of contexts (Homburg et al., 2015; Lemon and Verhoef, 2016) for example: branding (Brakus et al., 2009); retailing (Pucinelli et al., 2009; Verhoef et al., 2009); services (Arnould and Price, 1993; Edvardsson et al., 2005); and, online (Schouten et al., 2007). However, very few studies explore both customer and provider views of how to create high quality service encounters, exceptions include studies by Chandon et al., (1997), Lemke et al., (2011) and Winsted (2000). Additionally, most customer experience research is conducted in a B2C context, with significantly less in B2B (Palmer, 2010).

The few examples include: work examining the impact of 'customer experience' measures on brand equity (Biedenbach and Marell, 2010); the centrality of supplier understanding and value-in-use (Lemke et al., 2011); and, from an organisational level, the significance of multichannel interactions (Payne and Frow, 2004). Finally, in contrast to positive B2C experiences which are assumed to be "engaging, robust, compelling and memorable" (Gilmore and Pine, 2002, p.10), positive B2B experiences are trouble-free and reassuring (Meyer and Schwager, 2007) and based on reducing customer effort (Cardozo, 1965).

Other bodies of work study closely-related concepts, such as: quality, service experience and customer service. Indeed, Berry et al. (2006, p. 1) equate customer experience with customer service: "by definition, a good customer experience is good customer service, thus the customer experience is the service”. A developing stream of research explores customer experience from a co-creation perspective, wherein customer experience is seen as an interactive process between a customer and other actors, with all the actors being an integral part of the experience and, thus, part of the value creation process (Chandler and Lusch 2015; De Keyser et al. 2015; Frow and Payne, 2007; Prahalad and Ramaswamy 2003). In a review of the service experience literature Helkkula (2010, p.381) delineates three types of service experience: 'phenomenological service experience' (relating to value debates in 'service-dominant logic and interpretative consumer research'); 'process-based service experience' (relating to service as 'a sequential process'); and 'outcome-based service experience' (relating to experience of service linked to other 'variables or attributes' and 'various outcomes'). These categories capture the importance of service outcomes and distinguish between technical quality (the result of the service), and functional quality (the way the service is provided) as articulated by Grönroos (1984). 
As outlined by McColl-Kennedy's (2015) definition and other recent work (De Keyser et al., 2015; Lemon and Verhoef, 2016) customer experience comprises cognitive, emotional, affective, physical, sensorial, spiritual and social elements. Thus, whilst actors can share or co-create experiences, they perceive them individually (or phenomenologically) (Gentile et al., 2007). However, 'experiences' are also important because customers specifically select and purchase them, making a distinction between perceived experiences and the actual goods or services as part of their selection process (Arnould and Price, 1993). In a B2B context, capturing customer experience is further complicated because experience arises from direct and indirect interactions between suppliers, client and end users, as well as other actors involved in customer interaction. Thus, outcomes in customer experience are not simply individual perceptions but rather produce, and are a product of, interactions, described as 'touchpoints’ (Homburg et al., 2015 Schmitt, 2003; Pucinelli et al., 2009).

In B2C, touchpoints seem to be readily linked to a customer's purchase journey (Baxendale et al., 2015; Pucinelli et al., 2009; Verhoef et al., 2009). However, a holistic view of all the interactions a customer (and in the case of B2B customer experience, a 'user') has on this journey (Bolton et al., 2014) is needed for real understanding. This is further complicated within many B2B (service) contexts because touchpoints are more likely to occur across a wider range of front- and back-office functions and across firms too (Meyer and Schwager, 2007) and are not of equal value (Biedenbach and Marell, 2010) suggesting that employees might well offer a useful source of holistic customer experience knowledge. A B2C context tends to treat the firm and the customer as a monolithic entity, and only collect data about customer experiences at a few touchpoints, typically examining the gap between customers' expectations and their actual experience at the touchpoint (Meyer and Schwager, 2007). Such an approach potentially misses important touchpoints across the wider network of actors that are likely to be relevant in a B2B context, and thus, is unlikely to allow a holistic picture to be developed. Take, for example, a situation where a firm has outsourced its IT. There will be touchpoints between managers in both organisations to discuss whether Key Performance Indicators (KPIs) have been met, whilst their employees will be faced with a totally different set of touchpoints as they move through a fault fixing process. So we can see complex multiple customer experiences which may even be counterproductive when superficial fixes are applied in order to meet the KPI.

Customers possess an original combination of resources and utilise these in unique ways (Chandler and Lusch, 2015; De Keyser et al., 2015). They do this by matching and 
integrating resources and creating value through interacting in the wider service network (Gummesson and Mele, 2010). The central role of the customer here is important. Thus, we concur with McColl-Kennedy et al. (2015:4) who specifically argue that "to advance customer experience research and practice, a static, dyadic, organisation-centric perspective is no longer adequate”. Furthermore, we argue that other factors developed with reference to B2C customers, i.e. engagement and the importance of developing social capital, are also relevant to user experiences in a B2B (service) context, where interactions are still person-toperson. Lusch et al. (2010) suggest inter-active, co-creative customer experiences may be interpreted as the act of 'engaging'. Rather than simply considering interactions across various touchpoints, 'engaging' demonstrates a more active participation on the customer's part.

Lemon and Verhoef (2016) distinguish between the overlapping concepts of engagement and experience suggesting that the former is one element of the latter. Indeed, recent studies have also attempted to measure customer engagement (e.g., Brodie et al., 2013; Calder et al., 2016; Hollebeek et al., 2014), and to examine how firms can benefit from it (Pansari and Kumar, 2016). The experience aspect of customer engagement is important because it is considered a pre-requisite for social capital development (Onyx and Bullen, 2000; Mathwick et al., 2008). Social capital, defined as the social context (i.e. social ties, trusting relations, and value systems [Tsai and Ghoshal, 1998]) that facilitates the actions of individuals within a social context, establishes paths for knowledge transfer as well as reciprocal learning (Thibaut and Kelley, 1959). Thus, as an important facilitator of engagement and social capital, the different perspectives on customer experience, see Table 1, are likely to be foundational to our understanding of $\mathrm{B} 2 \mathrm{~B}$ relationships and the experiences that eminate from them. Hence it is important that appropriate measures are developed.

\section{Measuring Customer Experiences}

Customer experiences represent a growing field of interest within the wider service marketing literature, particularly in terms of B2C relationships. Whilst this paper is specifically interested in B2B relationships, customer feedback metrics have mainly been the focus of B2C researchers. These range from more general proxy measures for customer experience metrics related to customer satisfaction and willingness to recommend (de Haan et al., 2015; Meyer and Schwager, 2007) to more specific metrics, such as: service encounter quality (Jayawardhena et al., 2007) and service experience, which examines four experience dimensions: product experience, outcome focus, moments-of-truth, and peace-of-mind (Klaus 
and Maklan, 2012). A very popular, but also, heavily critiqued (de Haan, et al., 2015; Keiningham et al., 2007) customer feedback metric is Net Promoter Score (NPS). Developed by Reichheld (2003), this metric is used extensively by businesses as a customer experience metric, via a 'word of mouth' proxy measure. As an example of where it is being utilised in a context with great similarity to B2B is the National Health Service (NHS), here the purchaser is not the user (as is often the case in B2B). In the NHS it is used to assess the quality of the services being provided (including services by contracted suppliers); renamed as 'the Friends and Family Test'. This test asks patients one foundation question: 'how likely are you to recommend our services to your friends and family if they needed similar care or treatment?' The findings are ranked on a scale ranging from extremely likely to recommend, positively satisfied, to extremely unlikely to recommend. It represents a light touch approach and has been widely criticised in the health sector, not least in terms of who would recommend bowel cancer treatment to a friend? (see for instance Sizmur et al., (2015). In response to emerging criticisms surrounding the notion of recommendation and the logic of subtracting the cumulative score of lower ranking respondents from the cumulative score of higher ranking respondents, Dixon, Freeman and Toman (2010) offer a single measure, customer effort score (CES), which they argue has higher predictive power for repurchase and increased spend than NPS. However, both these measures currently fail to explain where the customer experience issues are, (which touchpoints? which contracted suppliers?), suggesting that use of these measures in isolation, will provide an insufficient measure of customer experience in B2B (service) contexts.

Customer experience proxy measures in a B2B setting have been reviewed by a small number of authors (see, for example, Biedenbach and Marell, 2010; Lemke et al., 2011; Rauyruen and Miller, 2007), who make reference to similar measurement mechanisms and approaches as in B2C. These include: service quality (Szmigin, 1993), service encounter quality (e.g. Jayawardhena et al., 2007), customer satisfaction (e.g. Homburg and Rudolph, 2001) and relationship quality (e.g. Naudé and Buttle, 2000; Ulaga and Eggert, 2006). Work distinguishes between aspects of service quality, as overall perceptions of a firm's service provision, and satisfaction, which is linked to individual service encounters (Jayawardhena et al., 2007). It is almost universally accepted that the quality of a service encounter can become a key strategic advantage over competitors (Jayawardhena et al., 2007; Mattila and Enz, 2002) and is fundamental in the development of customer value (Bolton and Drew, 1991; Cronin et al., 2000; Taylor and Baker, 1994). For others, the distinction between 
observable, involving the behaviours of customers, and unobservable measures, including customer perceptions, attitudes or intentions (Gupta and Zeithaml, 2006), is key. Customer behaviours typically include purchase, repurchase and communication in B2C contexts. In B2B contexts, collaborative resource deployment activities and solution development can also be observed. For example, a building services provider might work closely with several actors within a client firm to select, purchase, install and then operate a new boiler in the client's building, in order to achieve greater comfort for the client's personnel in tandem with improvements in energy efficiency and bills. The considerable overlap in the definition and measurement of unobservable metrics and the potential network effects such relationships generate represent important avenues for future research (Gupta and Zeithaml, 2006) and illustrate the challenges of their actual measurement.

One of the shortfalls impacting upon the collection of data in both the B2C and B2B contexts is that there is no agreement on how to go about this. In general, methods of collecting customer experience data are widely criticised (Wu et al., 2014) and understandably so; there is a great deal of variability in the research methods used, from surveys to face-to-face questionnaires, online forums, and observation (see Meyer and Schwager, 2007) and in the questions asked. Researchers and practitioners have traditionally used the standard toolkit of questionnaires, interviews, comment cards, focus groups, mystery shopper programmes and, more recently, analysis of social media dialogue. Standardised tools such as questionnaires may not capture all interactions, do not recognise that all touchpoints are not accessed by every actor, and often do not reflect that some touchpoints may be more important/valuable than others Approaches often focus on absolute metrics of a single firm, as opposed to relative metrics, whereas customers' perceptual assessments are measured relative to the competition (Keiningham et al., 2015). Indeed, Keiningham et al. (2011) suggest that relative brand ranking is more important in predicting buying behaviour than satisfaction. This poses an additional problem for B2B where branding is not always as prominent as it is in B2C.

For Meyer and Schwager (2007, p. 8) a "well-designed survey is not simply one that elicits the desired information. It must avoid becoming an unfortunate aspect of the customer experience”. Hence, those wishing to understand customer experience must consider whether their measurement practices are effective or whether they lead to bad customer experiences and customer frustration. It is also important to consider the quality of the measures and how firms can use them. Addressing the question of 'what is measured' suggests a reliance upon 
the collection of satisfaction data, with firms regularly asking customers, be they business client customers or end consumers, about their levels of satisfaction, both generally and related to specific experiences or interactions. Performance is often rated against KPIs, and is used to make sense of aspects such as service failure, loyalty and customer retention (Gounaris, 2005). It is widely accepted that performance measures serve not only as a tool to evaluate organisational activities, particularly when delivered by an outside provider as part of a service contract, but also as a way to promote the kinds of activities that are considered legitimate. Thus, better measures of customer experience might be those that match the organisation's business processes and the 'moments of truth' in service operations (Neely and Austin, 2002), through such things as performance-related incentives, e.g. performancerelated pay (Heinrich, 2007; Bovaird, 2014).

Customer experience studies suggest we should view service experience through the lens of the customer (Edvardsson et al., 2005; Verhoef et al., 2009). They also emphasise that value is co-created and uniquely defined by the customer (Frow and Payne, 2007; Vargo and Lusch 2004, 2012; Grönroos 2008, 2011; Grönroos and Voima, 2013) and that knowing where value resides has become crucial for managers (Ulaga and Chacour, 2001). However, the drive to deliver greater levels of satisfaction and, ultimately, higher performance - via market share or profitability has led to a drive to collect ever increasing quantities of feedback data (Neely and Austin, 2002). This has become easier with advances in technology; we have seen a rise in technology options, particularly in terms of collecting end consumer information, for example, pressing smiley faces as you pass through an airport terminal, screen based surveys as you wait for staff to scan items in retailers and facial recognition software to determine the mood of actors, used by both B2C and B2B companies to measure customer satisfaction with the various services provided (Froehle 2006; Greenburg, 2010; Herzig et al., 2016).

However, the data generated are often less than useful. As Neely and Austin state (2002, p. 48) there is a tendency to "measure everything that walks and moves, but nothing that matters.” [...] Too often managers in organisations are faced with spreadsheets full of numbers that are effectively meaningless”. These concerns are expressed across many sectors and extend to the amount and quality of customer feedback mechanisms and capabilities to quickly analyse and respond to generated insights (Ordenes et al. 2014). There are also concerns about how useful many of these measures are in practice or whether they overly rely 
upon easy to measure factors, which are, essentially, proxy measures, and are not necessarily strategically relevant either to the client or the service provider. As a result, there has recently been a shift in many contexts, such as construction and manufacturing, to move from more input-based measures towards more outcomes-based measures of performance (e.g., Bovaird, 2014; Callahan and Kloby, 2009; Lynch-Cerullo and Cooney, 2011; Mouzas, 2016; Selviaridis and Wynstra, 2015).

\section{Moving from Inputs-Outputs measures to Outcomes-based measures}

Burkett (2013, p. 88) suggests, that the move to outcomes-based measures shifts the question from 'Did they like it?' to a more strategic consideration of 'What difference did it make?'. For example, when examining building infrastructure, Koontz and Thomas (2012) note that input-output measures, such as building on time, on budget and to specification centres the attention narrowly on producing the infrastructure; by contrast, an outcomes-based measure would broaden the consideration of performance to include the end customer experience. So, outcomes-based measures would prompt questions that go beyond the building of infrastructure to consider why the infrastructure is needed in the first place. We see this, for instance, in a conventional infrastructure programme, where the focus on inputs-based performance measures would centre the attention on such key indicators as: the schedule; costs; and compliance with technical specifications. In so doing, the focus is firmly placed on providing infrastructure as a product, as opposed to considering infrastructure programme as a service to the end-users. By reorienting towards more outcomes-based metrics, we can move beyond a product-centric metric (do they deliver a bridge on time, on budget and to technical specification?) to a more strategic service-centric metric (How is this bridge helping to alleviate congestion, support economic growth and enhance and support the communities it serves?).

Recent work in the servitization arena (e.g., Smith et al., 2014), highlights significant benefits to traditionally product-dominant organisations of focusing on developing outcomes-based services. Ng et al. (2009) presented lessons learnt from the defence industry to see how outcomes-based contracts drove significant changes in systems thinking and the ways in which maintenance of aircraft systems were undertaken, citing the now famous Rolls-Royce TotalCare ${ }^{\circledR}$ model as an example from the aviation sector to illustrate how outcomes-based contracts can shift the attention away from selling products (e.g. engines, parts, repairs), to 
more strategic, co-created customer service concerns (i.e. reliable performance that allows airlines to use the engine for flying $x$ number of hours).

In another example, Robinson et al. (2016a) studied how a construction company transformed the way they created value for their customers. Conventionally, by focussing on input-output measures across the network, designers may propose certain solutions that are then vetoed by the contractor who may choose a heating and ventilation system that is cheaper but not necessarily reliable and cost-effective over the long term. By shifting towards an outcomes-based measure, e.g. comfort of patients, Robinson and colleagues (2016a and 2016b) observed a gradual shift towards contractors, product manufacturers and the end-customer co-creating value. The contractor started to make decisions not purely on cost but on through-life functionality for the end-customer. Product manufacturers began to integrate more intelligent features to capture the end-customer use of their equipment. This enabled the construction company to pay greater attention to the nuances of how heating and ventilation services were being used every day across the hospital and facilitated discussions with the client on how best to design systems and related service-level agreements.

These examples highlight that outcomes-based performance measures have the capacity to be more strategically nuanced and focused on interactive value co-creation. The focus shifts from asking how programme participants control these indicators to raising questions about the ultimate purpose of the service. They also highlight another challenge in that, it is not as simple as having joint KPIs, but rather it is in sharing the pain and gain that close partnerships and related performance outcome contracts can bring (Autry and Golicic, 2010; Carr and Pearson, 1999). Hence, we would argue that there is a strong case for considering outcomes-based measures as central to effective understanding and measurement of customer experience.

\section{Outcomes-based data and B2B customer experience}

In moving towards an outcomes-based performance measure, there is the potential to harness the power of co-creation to set agendas and facilitate value creation across all the participants involved, promote organisational learning, enable the judgement of performance to transcend organisational boundaries, and "bring data to life" (Callahan and Kloby, 2009, p. 6). However, in order to do this, researchers may well need to consider the whole B2B network, 
instead of narrowly focusing on one interaction dyad in isolation - usually either a businessto-end user dyad (B2C) or supplier-to-client dyad (B2B).

Outcomes-based measures are more consistent with a co-creation environment, as they offer clients a stronger role in inter-firm learning processes (Buckmaster, 1999; Eftimovska, et al., 2015), often a common goal for both customer and supplier firms. Customer involvement in product composition, delivery, and value is commonplace in B2B (Von Hippel et al., 2011). The service marketing literature since the 1970s has emphasised co-creation (Shostack, 1977), continued in the 1980s as 'interactive marketing' (Gummesson, 1987; Grönroos, 1982), and can be found more recently in the Service-Dominant Logic stream (Vargo and Lusch, 2008, 2004) and Service Logic stream of research (Grönroos, 2008; Grönroos and Voima, 2013) .

Outcomes-based data, by its very nature, supports this active engaged role as it relates directly to the consequences of service, as opposed to input data which focus on perceptions of service. As Peters et al. (2016), drawing on the work of Bardone and Secchi (2019), note, through enactment, customers and firms do not simply represent objects as abstract mental structures, but in fact enact cognitive performance that “... can be viewed as the result of smart interplay between humans and the environment” (Bardone and Secchi, 2019, p. 191). This highlights the fact that cognitive processes are not purely internal or mental processes, but in fact are complex interrelationships between human perception, interpretation, and sense-making and the wider environment in which they are situated such that tasks are conceptualised and commitment to goals are made. This reflects the view of intentionality (Bratman, 1987) as a specific form of human agency that represents the commitment of the individual to undertake actions and reach their goals. Furthermore, because outcomes-based data retain their link with the context of their creation, (i.e. they bear some connection with observable and measurable events- reflecting 'value-in-use': Vargo and Lusch, 2004); they are more useful in enhancing customer experience and strengthening customer relationships with a firm. We also contend that the use of outcomes-based data should move firms away from relying upon gathering proxy customer experience data from client customers or users.

Thus, the role of external resources (such as contextually-based data) is to help shape the representation of a task so as to transform difficult tasks into ones that can be easily 
understood, carried out, or enacted (Bardone and Secchi, 2009). Client and user experience, therefore, plays an important role in this dynamic interplay, helping to shape and drive how service contexts are perceived and as a result how tasks and goals are represented.

\section{The Role of Big Data in Customer Experience Measurement and Management}

Underpinning outcomes-based measures is a need to have robust data on product/service performance, yet in the past this has often been unavailable. However, technological developments have resulted in firms having the ability to generate a high volume of data, much faster than was previously available, and from a greater variety of different sources (Beulke, 2011) including: traditional enterprise data, machine-generated sensor data (e.g., smart meters), social data (Dijcks, 2013) and the capacity to handle these large, complex data sets (termed 'big data'). Some of this data can subsequently be turned into valuable information and exploited for competitive advantage (Opresnik and Taisch, 2015), if sufficient thought is put into how to gather, analyse and interpret it (Davenport et al., 2012). Equally, firms should consider how to handle their data assets and how to align them with existing IT systems for services and product development (Brown et al., 2006; Liftman et al., 2006). Ultimately, this process should result in organisational and cultural changes, and this is apparent in servitization, where outcomes-based measures have driven change in both client and supplier organisations (Baines and Lightfoot, 2014).

Through capturing data on end-users' experiences of using products, suppliers can enhance the quality of their existing offerings and develop new offerings (potentially by-passing other business partners) (Porter and Heppelman, 2014). For example, a supplier of office document management products would traditionally have little information on end-users' experiences of using their products, with second-hand data possibly reported via the customer's IT department. Now suppliers are able to capture real-time data on how individual end-users engage with their products, e.g., type and regularity of printing and technical issues during printing. This offers greater possibilities with regards to developing more complete profiles of end-users' experiences. Big data may, therefore, help to provide more accurate measures for service outcomes, and consequently customer experiences, than has previously been possible (LaValle, et al., 2011). 
However, despite providing more data and more detailed data, if all big data does is to provide more detailed measures of existing criteria, this will not necessarily be better or more helpful. Firms will, therefore, need to ensure that, rather than focusing on capturing and interrogating even more input-output-based data, they need to focus on capturing meaningful measures to realise the benefits that big data can bring. For example, within the shared print services sector, big data has the potential to provide a detailed breakdown of every faulty part that is replaced, which is useful from an inventory and cost perspective, but less useful for understanding customer experiences. However, the system is also able to provide data on the actual printing issues that have arisen for individual users, focusing on printer downtime during working hours, giving more insight into experience. Similarly, in the defence industry, moving the focus from the number of faulty parts that lead to lost flying-time to airworthy planes, outcomes-based measures, such as 'the amount of flight hours that were available and what specifically caused plane unavailability, helps the supplier and client to focus on measuring the key issues.

\section{Reconceptualising B2B Customer Experience}

In building on the ideas above, we offer a framework that attempts to capture a more strategic, dynamic and co-creation oriented approach to understanding B2B customer experience that is grounded in the notion of value-in-use and network interactions. In doing so we need to be cognisant that understanding customer experience in a B2B context is going to involve multiple interactions across different touchpoints with a variety of personnel involved and ensure that we prepare for the different expectations that may well relate to these interactions.

The framework is illustrated in Figure 2 below and shows the key differences between a more operational, static approach to measuring customer experience via input-output-based measures and a strategic, dynamic, and interactive approach to measuring customer experience via outcomes-based measures.

Essentially, the shift from providing services based on input-output measures to offering services based on outcome measures that support customers' objectives for value creation, is a strategic one that is both complex and difficult to make. Importantly, what gets measured gets managed and therefore changing from input/output measures to outcomes-based 
measures is the first step is this strategic process. Of course, to fully engage will take time and both client and provider will necessarily learn and adapt as a result of the process.

Figure 2 - Strategic Approach to Understanding Customer Experience: from input- and output-based measures to outcomes-based measures

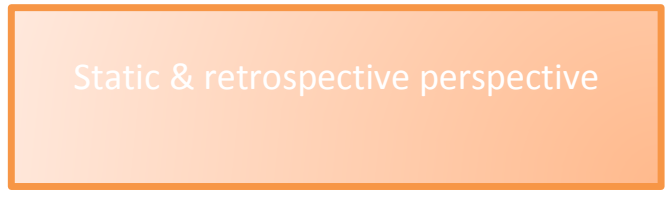

Input-output based measures

\section{Operational}

Measuring product-service performance (often service-level agreements)

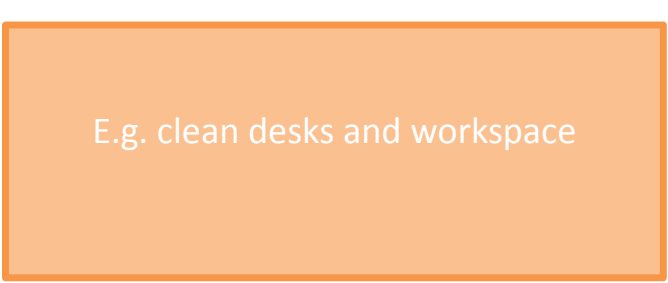

Dynamic \& interactive perspective

Outcomes-based measures

Value co-created by the whole B2B

network by focussing on outcomes for

all 'interim' and 'end' users in the

network (considering internal and

external customers' customers)

Strategic
Measuring how product-service

performance positively enhances the customer's business performance or other agreed outcomes

E.g. Workspace utilisation and better support for building users' work styles

The framework explicitly highlights an expectation that experiences need to be valued by clients and users and that contemporary B2B customer experience measurement research 
must understand the need for this value to be co-created. This emphasises that B2B services that deliver effective customer experiences are those that consider a longer-term value proposition, beyond the point of sale. This approach supports the notion that experience is phenomenologically understood, allowing firms to shift from a focus on consistent measurement of what can amount to potentially meaningless measures, such as the smiley faces appearing at the exits of experience-based services, to the measurement of meaningful outcomes-based customer experience. If, in the context of customer experience, firms can appreciate and measure what represents value for clients and users by co-creating those measures with the clients and users, and if they can align the co-creation of that value with their own strategic objectives, this creates powerful outcomes. It matters less that customer A's experience cannot be easily compared with customer B's experience - because the focus instead is on co-created objectives.

These measures should not be seen in isolation from the experience that is the focus of the measure, but rather, need to be considered in the context of the dynamic, relational process that this is part of. Service customers' experiences may iteratively flow back and forth between current, future, and past experiences, because current experiences can and do affect how a customer makes sense of past and future experiences (Helkkula et al., 2012). Thus, the time dimension needs to be taken into consideration when trying to measure outcomes. Triggers for measuring outcome status will also need to be considered; these triggers could be routine reviews of the process but equally could come from intelligence from service or product personnel, actors in the wider network or through analytics derived from big data/ the Internet of Things (IoT).

In focusing on outcomes, there is the potential to use a variety of different measures, including those provided by technology and by other informants. These measures should be designed to cover multiple aspects of the experience and, thus, take into account how cognitive, affective, emotional, social and physical outcomes can be measured, as well as the front- and back- stage touchpoints that have framed the experience. Importantly, there has been a tendency to forget that many service experiences are interactive and that employees are intrinsically involved. It seems that employees are rarely used as sources of information (Burns et al., 2013), often because of assumptions that they might be inclined toward selfinterest in their responses as well as because of the difficulty of capturing that information. 
However, given the potential insight inherent in their knowledge, it seems remiss not to find a way to include their insights.

\section{Conclusions and Implications}

What is clear from the literature is that there are numerous approaches to collecting customer feedback, some of which measure customer experience, and some of which do not. There are also a similar number of critiques of these approaches. To paraphrase Silverman (2006, p. 390), in objectively studying the conditions and consequences of customer experience, or in qualitatively examining customer responses to interventions intended to improve their experience, the phenomenon of 'customer experience' disappears. That is, existing measures of customer experience, whether quantitative or qualitative, end up a-contextual. If we then look at what firms do in response to these data, as a mechanism to achieve 'satisfied' customers, they focus on the wrong metrics that are largely input- and output-based. We, therefore, need to seriously question whether these measures are being employed simply as hygiene factors, i.e. minimum standards deemed necessary to prevent customer dissatisfaction. Furthermore, they generally only focus upon one part of the experience, neglecting to explore the experience of customers and users across various service touchpoints and ignoring difficult to measure but key customer experience aspects, such as emotional response.

The concern here is whether this ongoing measurement of end users' perceptions is actually supporting the creation of good customer experiences, or actually creating customer dissatisfaction or enragement, as they become increasingly frustrated at having to constantly evaluate their experiences. We also typically measure perceptions of customer experience, mainly at touchpoints, which are more transactional or at best episodic level measures. This is problematic in that concepts such as 'experience' and 'satisfaction' are often understood very differently by different respondents; and there is related confusion over their interpretation.

Thus, we argue that improving customer experience is not about getting more data, or more accurate customer measures. There is a lot of rhetoric about customer experience and we need to move away from this to more effectively action the central tenets of experience that will improve not only customer relationships but also profitability. Instead of thinking about and focusing on satisfaction and loyalty/repeat business, managers need to understand more about what their customer experience journeys comprise, and how these elements relate to 
their tactical and strategic goals. Importantly, firms will need to eschew the current focus on generating consistent measures of customer experience (which may be comparable across customers, across business units and across different service level agreements but may not be effectively measuring or offering useful information for positively influencing customer experience). In contrast, we suggest that researchers and managers may need to switch to more idiosyncratic measures, so that client customer's and user's experiences are meaningfully measured and appropriately influenced. In this regard, we may need to (literally and metaphorically) measure less (at least, stop persistently measuring customer experience perceptual proxies) and understand more. Ultimately, we expect that this will create a more virtuous circle in which what is measured is meaningful and the service experience is influenced positively for service providers, clients and users. Rather than being outcome measures that are considered in their own right, measures of customer experience become the platform on which co-creation opportunities are built and maintained. As both organisations learn about what is strategically important to them (and how to measure this), new outcomesbased measures will emerge that create and sustain the cycle again and again.

This change in thinking about measurement of customer experience is important in that it represents a shift in our understanding from the managerial control of some 'thing' (such as information) to the development of subjective and contextual intellectual capital. This shift acknowledges the importance of knowledgeability as a key aspect of value co-creation in that the focus for managerial action now moves away from the management of data and information through information storage, dissemination and access, and shifts to a focus on the knowledgeability of employees and clients, and to managerial decision-making.

Thus, delivering an outcomes-based approach to understanding customer experience is likely to require the development of new capabilities. We would argue that a focus on the generation and utilisation of outcome data better supports opportunities to learn for all parties in the network. This is because it offers the opportunity to support both customer and firm learning by focusing on the actual and measurable events that can be observed. It also recognises that customer expertise plays an important part in developing relationships with supplier firms. Customer relationship building capabilities, driven by industry-level changes, emphasise "that the involvement of other parties is important since product and process innovations often come from suppliers, architects and consultants and from the collaboration between them” (Bygballe et al. 2010, p. 244). This represents what Macdonald and Uncles 
(2007) termed a new ethos of customer literacy, with an emphasis on relations of collaboration, participation, dispersion and distributed expertise.

Clearly our paper is constrained by being conceptual, rather than empirically grounded. However, in drawing on other research disciplines and contexts, we believe that the alternative approach to measuring B2B customer experience that we propose has merit. We outline below a future research agenda to respond to this limitation.

Given the current levels of disenchantment with more traditional measurement approaches, work needs to be done to redevelop appropriate measures of service experience outcomes. Specifically, we need to establish whether current user experience metrics are the most useful mechanism for assessing customer experience, and whether there are alternative measures that could provide similar or better information that is more managerially useful. Future research could also look to empirically test the ideas presented in the strategic customer experience framework. Specifically, future research might focus more on the interactions, front line employees and the wider network in terms of how they can support the assessment and generation of customer experience as well as how time impacts upon this. While there has been some research in this area, e.g. Homburg and Rudolf (2001), Zolkiewski et al. (2007) and Carreira et al. (2013), this only reveals the complexities at play rather than giving insight as to how we might collect meaningful data in this area. Achieving this might well lead researchers into the domains of knowledge management and organisational capabilities. While much attention has been afforded to the knowledge held by firms and their knowledge dissemination practices, less attention has been directed towards knowledge and learning and capability development at the level of the network. Finally, work should also begin to explore the similarities and differences across different sectors and B2B contexts.

\section{References}

Abbott, L. (1955), Quality and Competition. New York: Columbia University Press.

Arnould, E. J., and Price, L. L. (1993), "River magic: Extraordinary experience and the extended service encounter”, Journal of Consumer Research, Vol. 20 (June), pp. 2445. 
Autry, C.W. and Golicic, S.L. (2010), "Evaluating buyer-supplier relationship-performance spirals: A longitudinal study”, Journal of Operations Management, Vol. 28, pp. 87100.

Baines, T. and Lightfoot, H. (2014), "Servitization of the manufacturing firm. Exploring the operations practices and technologies that deliver advanced services”, International Journal of Operations Management, Vol. 34, No. 1, pp. 2-35.

Bardone, E. and Secchi, D. (2009), "Distributed cognition: A research agenda for management”, In M. Afzalur Rahim and M. Rahim (Ed.), Current Topics in Management. Organizational Behavior, Performance, and Effectiveness, Vol. 14, pp. 183-207: New Brunswick, NJ: Transaction Publishers.

Barry, J. and Terry, T.S. (2008. "Empirical study of relationship value in industrial services”, Journal of Business \& Industrial Marketing, Vol. 23, No. 4, pp. 228-241.

Baxendale, S., Macdonald, E.K. and Wilson, H.N. (2015), "The impact of different touchpoints on brand consideration”, Journal of Retailing, Vol. 91, No. 2, pp. 235253.

Berry, L., Wall, E. and Carbone, L. (2006), "Service clues and customer assessment of the service experience: Lessons from marketing”, Academy of Management Perspectives, Vol. 20, No. 2, pp. 43-57.

Beulke, D. (2011), "Big data impacts data management: The 5Vs of big data”. Available from: Big Data Impacts Data Management: The $5 \mathrm{Vs}$ of Big Data, accessed $21^{\text {st }}$ January 2016.

Biedenbach, G. and Marell, A. (2010), “The impact of customer experience on brand equity in a business-to-business service setting”, Journal of Brand Management, Vol. 17, No. 6, pp. 446-458.

Bolton, R.N., and Drew, J.H. (1991), “A multistage model of customers' assessments of service quality and value”, Journal of Consumer Research, Vol. 17, No. 4, pp. 375384.

Bolton, R.N., Gustafsson, A. McColl-Kennedy, J., Sirianni, N.J. and Tse, D.K. (2014), "Small details that make big differences: A radical approach to consumption experience as a firm's differentiating strategy”, Journal of Service Management, Vol. 25, No. 2, pp. 253-274.

Bovaird, T. (2014), “Attributing outcomes to social policy interventions: 'Gold Standard' or 'Fool's Gold' in public policy and management?’, Social Policy and Administration, Vol. 48, No. 1, pp. 1-23. 
Brakus, J.J., Schmitt, B.H. and Zarantonello, L. (2009), "Brand experience: What is it? How is it measured? Does it affect loyalty?" Journal of Marketing, Vol. 73. No. 3, pp. 5268.

Bratman, M.E. (1987), Intention, plans, and practical reason. Cambridge, MA: Harvard University Press.

Brodie, R.J., Ilic, A., Juric, B. and Hollebeek, L., (2013), “Consumer engagement in a virtual brand community: An exploratory analysis“, Journal of Business Research, Vol. 66, No.1, pp.105-114.

Brown, G.W., Dermikan, H., Goul, M. and Mitchell, M. (2006), “Towards the serviceoriented enterprise vision: Bridging industry and academics”. Panel Presentation American Conference on Information System, 4-6 August. Acapulco, Mexico

Buckmaster, N. (1999), “Associations between outcome measurement, accountability and learning for non-profit organisations”, International Journal of Public Sector Management, Vol. 12, No. 2, pp. 186-197.

Bughin J., Chui, M., and Manyika, J. (2010), “Clouds, big data, and smart assets: ten techenabled business trends to watch”, McKinsey Quarterly, Vol. 56, No.1, pp. 75-86

Burkett, H. (2013), “Moving from outputs to outcomes in the public health sector: a case study”, Journal of the Grant Professionals Association, Vol. 11, No. 1, pp. 84-95.

Burns, M., Manning, H. and Stone, A. (2013), "The state of customer experience management, 2013”, Cambridge, MA: Forrester, March 22, 2013, pp. 1-19.

Bygballe, L.E., Jahre, M., and Sward, A. (2010), "Partnering relationships in construction: a literature review”, Journal of Purchasing and Supply Management, Vol. 16, pp. 239253.

Calder, B.J., Isaac, M.S., and Malthouse, E.C. (2016), "How to capture consumer experiences: A context-specific approach to measuring engagement”, Journal of Advertising Research, Vol. 56, No. 1, pp. 39-52.

Callahan, K. and Kloby, K. (2009), Moving Toward Outcome-Oriented Performance Measurement Systems. IBM Center for the Business of Government.

Cardozo, R.N. (1965), “An experimental study of customer effort, expectation, and satisfaction”, Journal of Marketing Research, Vol. 2, No. 3, pp. 244-249.

Carr, A.S. and Pearson, J.N. (1999), "Strategically managed buyer-supplier relationships and performance outcomes”, Journal of Operations Management, Vol. 17, pp. 497-519. 
Carreira, R., Patrício, L., Jorge, R.N. and Magee, C.L. (2013), “Development of an extended Kansei engineering method to incorporate experience requirements in product-service system design”, Journal of Engineering Design, Vol. 24, No. 10, pp. 738-764.

Chandon, J.-L., Leo, P.-Y., and Philippe, J. (1997), "Service encounter dimensions - a dyadic perspective: Measuring the dimensions of service encounters as perceived by customers and personnel”, International Journal of Service Industry Management, Vol. 8, No. 1, pp. 65-86.

Chumpitaz Caceres, R., and Paparoidamis, N.G. (2007), "Service quality, relationship satisfaction, trust, commitment and business-to-business loyalty”, European Journal of Marketing, Vol. 41, No. 7/8, pp. 836-867.

Chandler, J.D. and Lusch, R.F. (2015), "Service systems: A broadened framework and research agenda on value propositions, engagement, and service experience”, Journal of Service Research, Vol. 18, No. 1, pp. 6-22.

Cronin, J.J., Brady, M.K., \& Hult, G.T.M. (2000), “Assessing the effects of quality, value, and customer satisfaction on consumer behavioral intentions in service environments”, Journal of Retailing, Vol. 76, No. 2, pp. 193-218.

Davenport, T., Barth, P., Bean, R. (2012), "How “Big Data” is different”, MIT Sloan Management Review, Vol. 54, pp. 21-24.

De Haan, E., Verhoef, P.C. and Wiesel, T. (2015), “The predictive ability of different customer feedback metrics for retention”, International Journal of Research in Marketing, Vol. 32, No. 2, pp. 195-206.

De Keyser, A., Lemon, K.N., Keiningham, T .and Klaus, P. (2015), “A framework for understanding and managing the customer experience”, MSI Working Paper Series (15-121), Cambridge, MA: Marketing Science Institute.

Dijcks J-P. (2013), Oracle: big data for the enterprise. Redwood Shores, Oracle.

Dixon, M, Freeman, K. and Toman, N. (2010), “Stop trying to delight your customers”, Harvard Business Review, Vol. 88, No. 7/8 , pp. 116-122.

Edvardsson, B., Gustafsson, A. and Roos, I. (2005), "Service portraits in service research - a critical review”, International Journal of Service Industry Management, Vol. 16, No. 1, pp. 107-121.

Edvardsson, B., Tronvoll, B. and Gruber, T. (2011), “Expanding understanding of service exchange and value co-creation: a social construction approach”, Journal of the Academy of Marketing Science, Vol. 39, pp. 327-339. 
Eftimovska, E., Lind, C., Hager., A., Wasson, J.H. and Lindblad, S. (2015), "Patient reported outcome measures in practice”, British Medical Journal, Vol. 350, pp. 7818.

Epp, A.M. and Price, L.L. (2011), “Designing solutions around customer network identity goals”, Journal of Marketing, Vol. 75, No. 2, pp. 36-54.

Froehle, C.M. (2006). "Service personnel, technology, and their interaction in influencing customer satisfaction”, Decision Sciences, Vol.37, No. 1, pp.5-38.

Frow, P. and Payne, A. (2007), “Towards the 'perfect' customer experience”, Brand Management, Vol. 15, No. 2, pp. 89-101.

Gentile, C., Spiller, N. and Noci, G. (2007), "How to sustain the customer experience: An overview of experience components that co-create value with the customer", European Management Journal, Vol. 25, No. 5, pp. 395-410.

Geyskens, I. Steenkamp, J.-B.E.M. and Kumar, N. (1999), “A meta-analysis of satisfaction in marketing channel relationships”, Journal of Marketing Research, Vol. 36, May, pp. 223 - 238.

Gilmore, J. and Pine, B. (2002), “Customer experience places: The new offering frontier”, Strategy and Leadership, Vol. 30, pp. 4-11.

Greenberg, P. (2010)."The impact of CRM 2.0 on customer insight", Journal of Business \& Industrial Marketing, Vol. 25, No. 6, pp. 410 -419.

Gounaris, S.B. (2005), “Trust and commitment influences on customer retention: Insights from business-to-business services”, Journal of Business Research, Vol. 58, pp. 126140.

Grönroos, C. (1982), “An applied service marketing theory”, European Journal of Marketing, Vol. 16, No. 7, pp. 30-41.

Grönroos, C. (1984), “A service quality model and its marketing implications”, European Journal of Marketing, Vol. 18, No. 4, pp. 36-44.

Grönroos, C. (2008), “Service logic revisited: who creates value? And who co-creates?”, European Business Review, Vol. 20, No. 4, pp. 298-314.

Grönroos, C. (2011), “A service perspective on business relationships: The value creation, interaction and marketing interface”, Industrial Marketing Management, Vol. 40, pp. 240-247.

Grönroos, C. and Voima, P. (2013), “Critical service logic: Making sense of value creation and co-creation”, Journal of the Academy of Marketing Science, Vol. 41, pp. 133-150. 
Gummesson, E. (1987), “The new marketing: developing long-term interactive relationships”, Long Range Planning, Vol. 5, No. 5, pp. 5-20.

Gummesson, E., and Mele, C. (2010), "Marketing as value co-creation through network interaction and resource integration”, Journal of Business Market Management, Vol. 4, No. 4, 181-198.

Gupta, S. and Zeithaml, V. (2006), “Customer metrics and their impact on financial performance”, Marketing Science, Vol. 25, Vol. 6, pp. 718-739.

Håkansson, H., Ford, D., Gadde, L.-E., Snehota, I. and Waluszewski, A. (2009), Business in Networks. Chichester, England: John Wiley \& Sons Ltd.

Heinrich, C.J. (2007), "False or fitting recognition? The use of high performance bonuses in motivating organizational achievements”, Journal of Policy Analysis and Management, Vol. 26, No. 2, pp. 281-304.

Helkkula, A. (2010), “Characterising the concept of service experience”, Journal of Service Management, Vol. 22, No. 3, pp. 367-389.

Helkkula, A., Kelleher, C. and Pihlstro, M. (2012), "Characterizing value as an experience: implications for service researchers and managers”, Journal of Service Research, Vol. 15, No. 1, pp. 59-75.

Herzig, J., Feigenblat, G., Shmueli-Scheuer, M., Konopnicki, D. and Rafaeli, A. (2016), "Predicting customer satisfaction in customer support conversations in social media using affective features”, in Proceedings of the 2016 Conference on User Modeling Adaptation and Personalization (pp. 115-119). ACM.

Hollebeek, L.D., Glynn, M.S. and Brodie, R.J., 2014. Consumer brand engagement in social media: Conceptualization, scale development and validation. Journal of interactive marketing, Vol. 28, No. 2, pp.149-165.

Homburg, C., Allmann, J., and Klarmann, M. (2014), “Internal and external price search in industrial buying: The moderating role of customer satisfaction”, Journal of Business Research, Vol. 67, pp. 1581-1588.

Homburg, C., Jozić, D., and Kuehnl, C. (2015), “Customer experience management: towards implementing an evolving marketing concept”, Journal of the Academy of Marketing Science, online 19 August 2015; DOI 10.1007/s11747-015-0460-7.

Homburg, C. and Rudolph, B. (2001), "Customer satisfaction in industrial markets: dimensions and multiple role issues”, Journal of Business Research, Vol. 52, pp. 1523. 
Jayawardhena, C., Souchon, A.L., Farrell, A.M. and Glanville, K. (2007), “Outcomes of service encounter quality in a business-to business context”, Industrial Marketing Management, Vol. 36, pp. 575-588.

Keiningham, T.L., Aksoy, L., Buoye, A. and Cooil, B. (2011), “Customer loyalty isn’t enough. grow your share of wallet”, Harvard Business Review, October, pp. 29-31.

Keiningham, T.L., Cooil, B., Andreassen, T.W. and Aksoy, L. (2007), “A longitudinal examination of net promoter and firm revenue growth”, Journal of Marketing, Vol. 71, No. 3, pp. 39-51.

Keiningham, T.L., Cooil, B., Malthouse, E.C., Buoye, A., Aksoy, L., De Keyser, A. and Lariviere, B. (2015), "Perceptions are relative: An examination of the relationship between relative satisfaction metrics and share of wallet”, Journal of Service Management, Vol. 26, No. 1, pp. 2-43.

Klaus, P. and Maklan, S. (2012), "EXQ: A multiple-item scale for assessing service experience”, Journal of Service Management, Vol. 23, No. 1, pp. 5-33.

Koontz, T.M. and Thomas, C.W. (2012), "Measuring the performance of public-private partnerships”, Public Performance and Management Review, Vol. 35, No. 4, pp. 769786.

Pansari, A. and Kumar, V. (2016), “Customer engagement: the construct, antecedents, and consequences.” Journal of the Academy of Marketing Science, pp.1-18.

LaValle, S., Lesser, E., Shockley, R., Hopkins, M.S., and Kruschwitz, N. (2011), "Big data, analytics and the path from insights to value”, MIT Sloan Management Review, Vol. 52, No. 2, pp. 21-31.

Lemke, F, Clark, M. and Wilson, H. (2011), "Customer experience quality: an exploration in business and consumer contexts using repertory grid technique," Journal of the Academy of Marketing Science, Vol. 39, No. 6, pp. 846-869.

Lemon, K.N. and Verhoef, P.C. (2016), “Understanding customer experience throughout the customer journey”, Journal of Marketing, JM-MSI Special Issue, May 20, 2016. DOI: $10.1509 / j m .15 .0420$

Liftman, J., Kempaiah, R. and Nash, E. (2006), "Key issues for IT executives”, MIS Quarterly Executive. Vol. 5, No. 2, pp. 27-45.

Lusch, R.L., Vargo, S.L. and Tanniru, M. (2010), “Service, value-networks, and learning”, Journal of the Academy of Marketing Science, Vol. 38, No. 1, pp. 19-31.

Lynch-Cerullo, K. and Cooney, K. (2011), “Moving from outputs to outcomes: a review of 
the evolution of performance measurement in the human service nonprofit sector”, Administration in Social Work, Vol. 35, No. 4, pp. 364-388.

Macdonald, E. and Uncles, M. (2007), "Consumer savvy: Conceptualisation and measurement”, Journal of Marketing Management, Vol. 23, No. 5-6, pp. 497-517.

Manary, M.P., Boulding, W., Staelin, R. and Glickman, S.W. (2012), “The patient experience and health outcomes”, The New England Journal of Medicine, Vol. 368, pp. 201-203.

Mathwick, C., Wiertz, C., and Ruyter, K.D. (2008), "Social capital production in a virtual P3 community”, Journal of Consumer Research, Vol. 34, No. 6, pp. 232-249.

Mattila, A.S. and Enz, C.A. (2002), “The Role of Emotions in Service Encounters”, Journal of Service Research, Vol. 4, No. 4, pp. 268-277.

McColl-Kennedy, J.R., Gustafsson, A., Jaakkola, E., Klaus, P., Radnor, Z.J., Perks, H. and Friman, M. (2015), “Fresh perspectives on customer experience”, Journal of Services Marketing, Vol. 29(6/7), pp. 430-435.

Meyer, C. and Schwager, A. (2007), "Understanding customer experience”, Harvard Business Review, Vol. 85, No. 2, pp. 117-126.

Mikolon, S., Kolberg, A., Haumann, T. and Wieseke, J. (2015), “'The complex role of complexity: How service providers can mitigate negative effects of perceived service complexity when selling professional services”, Journal of Service Research, Vol. 18, No. 4, pp. 513-528.

Mouzas, S. (2016), "Performance based contracting in long-term supply relationships”, Industrial Marketing Management, Vol. 59, November, pp. 50-62.

Naudé, P. and Buttle, F. (2000), “Assessing relationship quality”, Industrial Marketing Management, Vol. 29, pp. 351-361.

Neely, A. and Austin, R. (2002), "Measuring performance: the operations perspective”, In: A. Neely (Ed.) Business Performance Measurement: Theory and practice. Cambridge: Cambridge University Press. pp. 41-50.

Ng, I.C.L., Maull, R. and Yip, N. (2009), “Outcome-based contracts as a driver for systems thinking and service-dominant logic in service science: evidence from the defence industry”, European Management Journal, Vol. 27, No. 6, pp. 377-387.

Onyx, J. and Bullen, P. (2000), "Measuring social capital in five communities”, The Journal of Applied Behavioral Science, Vol. 36, No. 1, pp. 23-42.

Opresnik D. and Taisch M. (2015), “The value of big data in servitization”, International Journal of Production Economics, Vol. 165, pp. 174-184 
Ordenes, F.V., Theodoulidis, B., Burton, J., Gruber, T. and Zaki, M. (2014), “Analyzing customer experience feedback using text mining a linguistics-based approach”, Journal of Service Research, Vol. 17, No. 3, pp. 278-295. Palmer, A. (2010), “Customer experience management: a critical review”, Journal of Services Marketing, 24(3), pp. 196-208.

Payne, A. and Frow, P. (2004), "The role of multi-channel integration in customer relationship management”, Industrial Marketing Management, Vol. 33, pp. 527-538.

Peters, L., Pressey, A. and Johnston, W. (2016), “Contingent factors affecting network learning”, Journal of Business Research, Vol. 69, No.7, pp. 2507-2515.

Porter, M. E. and Heppelmann, J.E. (2014), “How smart connected products are transforming competition”, Harvard Business Review, November, pp. 65-88.

Prahalad, C.K. and Ramaswamy, V. (2003), “The new frontier of experience innovation”, MIT Sloan Management Review, Vol. 44, No.4, pp. 12-18.

Pucinelli, N.M., Goodstein, R.C., Grewal, D., Price, R., Raghubir, P. and Stewart, D. (2009), “Customer experience management in retailing: Understanding the buying process", Journal of Retailing, Vol. 85 (Mar), pp. 15-30.

Rauyruen, P. and Miller, K.E. (2007), "Relationship quality as a predictor of B2B customer loyalty”, Journal of Business Research, Vol. 60, No. 1, pp. 21-31.

Reichheld, F.F. (2003), “The one number you need to grow”, Harvard Business Review, December, pp. 1-11.

Robinson, W., Chan, P. and Lau, T. (2016a), "Finding new ways of creating value: A case study of servitization in construction”, Research-Technology Management, Vol. 59, No. 3, pp. 37-49.

Robinson, W.G., Chan, P.W. and Lau, T. (2016b), “Sensors and sensibility: Examining the role of technological features in servitizing construction towards greater sustainability”, Construction Management and Economics, Vol. 34, No. 1, pp. 4-20.

Schmitt, B.H. (2003), Customer experience management: A revolutionary approach to connecting with your customers. Hoboken: Wiley.

Schouten, J.W., McAlexander, J.H. and Koenig, H.F. (2007), “Transcendent customer experience and brand community”, Journal of the Academy of Marketing Science, Vol. 35, No. 3, pp. 357-368.

Selviaridis, K. and Wynstra, F. (2015), "Performance-based contracting: a literature review and future research directions”, International Journal of Production Research, Vol. 53, No. 12, pp. 3505-3540. 
Shostack, G. L., (1977), “Breaking free from product marketing”, Journal of Marketing, Vol. 41, No. 2, pp. 73-80.

Silverman, D. (2006), Interpreting Qualitative Data: Methods for analysing talk, text and interaction. 3 Ed. London: Sage.

Sizmur, S., Graham, C. and Walsh, J. (2015), “Influence of patients' age and sex and the mode of administration on results from the NHS Friends and Family Test of patient experience”, Journal of Health Services Research \& Policy, Vol. 20, No. 1, pp.5-10.

Smith, L., Maull, R. and Ng, I. (2014), “Servitization and operations management: a service dominant-logic approach”, International Journal of Operations \& Production Management, Vol. 34, No. 2, pp. 242-269.

Story, V.M., Raddats, C. Burton, J., Zolkiewski, J. and Baines, T. (2016), “Capabilities for advanced services: A multi-actor perspective”, Industrial Marketing Management (2016), http://dx.doi.org/10.1016/j.indmarman.2016.04.015

Szmigin, I. (1993), “Managing quality in business-to-business services”, European Journal of Marketing, Vol. 27, No. 1, pp. 5-21.

Taylor, S.A. and Baker, T.L. (1994), “An assessment of the relationship between service quality and customer satisfaction in the formation of consumers' purchase intentions”, Journal of Retailing, Vol. 70, No. 2, pp. 163-178.

Thibaut, J.W. and Kelley, H.H. (1959), The Social Psychology of Group, New York: John Wiley.

Tsai, W. and Ghoshal, S. (1998), "Social capital and value creation: The role of intrafirm networks”, The Academy of Management Journal, 41(4), pp. 464-476.

Ulaga, W. and Chacour, S. (2001), "measuring customer-perceived value in business markets: a prerequisite for marketing strategy development and implementation”, Industrial Marketing Management, Vol. 30, pp. 525-540.

Ulaga, W. and Eggert, A. (2006), "Relationship Value and relationship quality: broadening the nomological network of business-to-business relationships”, European Journal of Marketing, Vol. 40, No. 3/4, pp. 311-327.

Vargo, S.L. and Lusch, R.F. (2004), "Evolving to a new dominant logic for marketing”, Journal of Marketing, Vol. 68, No. 1, pp. 1-17.

Vargo, S.L. and Lusch, R.F. (2008), “Service-dominant logic: continuing the evolution”, Journal of the Academy of Marketing Science, Vol. 36, No.1, pp. 1-10.

Vargo, S.L. and Lusch, R.F. (2012), “The nature and understanding of value: A servicedominant logic perspective”, in Vargo, S.L. and Lusch, R.F.(ed.) Special Issue - 
Toward a Better Understanding of the Role of Value in Markets and Marketing (Review of Marketing Research, Volume 9), Emerald Group Publishing Limited, pp. $1-12$.

Verhoef, P.C., Lemon, K.N., Parasuraman, A., Roggeveen, A., Tsiros, M. and Schlesinger L.A. (2009), "Customer experience creation: determinants, dynamics and management strategies," Journal of Retailing, Vol. 85, No.1, pp. 31-41.

Von Hippel, E., Ogawa, S. and de Jong, J. (2011) "The age of the consumer-innovator“, Sloan Management Review, Vol. 53, No. 1, pp. 27-35.

Winsted, K.F. (2000), "Service behaviours that lead to satisfied customers", European Journal of Marketing, Vol. 34, No. 3/4, pp. 399-417.

Wu, P.-L., Yeh, S.-S., Huan T.-C. (T.C.) and Woodside, A.G. (2014), “Applying complexity theory to deepen service dominant logic: Configural analysis of customer experienceand-outcome assessments of professional services for personal transformations”, Journal of Business Research, Vol. 67, pp. 1647-1670.

Wynstra, F., Axelsson, B., and van der Valk, W. (2006), An application-based classification to understand buyer-supplier interaction in business services. International Journal of Service Industry Management, Vol. 17, No. 5, pp. 474-496.

Zolkiewski, J., Lewis, B. Yuan, F. and Yuan, J. (2007),"An assessment of customer service in business-to-business relationships", Journal of Services Marketing, Vol. 21, No.5, pp. 313-325. 